\title{
Evaluation of Bronchoprotective Effect of Ferula Asafetida in Guinea pigs
}

\author{
Bandana Rath ${ }^{1}, \mathrm{C}$ S Maharana ${ }^{2}$, Sadananda Rath $^{3}, \mathrm{D}$ J Mahakul ${ }^{4}$ \\ ${ }^{I}$ Dr Bandana Rath, Assoc. Professor, Pharmacology, MKCG Medical College, Berhampur \\ ${ }^{2}$ Dr Chandra SekharMaharana, Professor HOD, Pharmacology, MKCG Medical College, Berhampur \\ ${ }^{3}$ Dr Sadananda Rath, Professor HOD, Anatomy, MKCG Medical College, Berhampur \\ ${ }^{4}$ Mr D J Mahakul, student, MKCG Medical College, Berhampur
}

\begin{abstract}
:
Background:In traditional medicine, asafetida obtained from rhizomes of Ferula asafetida plant is used for whooping cough, pneumonia, bronchitis and bronchial asthma.

Objective:This study aimed to evaluate the bronchoprotective effect of aqueous extract of Ferula asafetida gum on histamine induced bronchospasm in Guineapigssand its potential mast cell stabilizing activity.

Materials and Method: In this study, the aqueous extract of Ferula asafetida gum was subjected for preliminary phytochemical screening. Its effect on histamine induced bronchospasm in guineapigs and Compound 48/80 induced mast cell degranulation was evaluated at different doses.

Results:Ferula asafetida gum extract offered a highly significant bronchoprotection in a dose dependent manner $(p<0.001)$. With 10 and $100 \mu \mathrm{g} / \mathrm{ml}$ it significantly reduced the disrupted mast cell count following C48/80 challenge. $(p<0.05)$ Volatile oils, resins, ferulic acid, terpenes, flavonoids and steroids were identified in ferula gum on Phytochemical screening

Conclusion:The brochoprotective effect of ferula might be due to its antihistaminic and mast cell stabilizing activity imparted by its phytoconstituents.
\end{abstract}

Keywords:Ferula asafoetida, aqueous gum extract, bronchoprotection, mast cell degranulation, Compound $48 / 80$

\section{Introduction}

Bronchial asthma is a common health problem characterized by increase responsiveness of the tracheo bronchial tree.[1]No longer it can be viewed simply as reversible airway obstruction. Now it is viewed primarily as inflammatory illness that leads to bronchial hyper-reactivity and bronchospasm as a result.[2] This can be caused by a wide variety of exogenous and endogenous stimuli. After unfolding the pathophysiology of bronchial asthma as a primary inflammatory disease of bronchial tree, which leads to broncho-constriction, marked changes in drug therapy, both for relief and prevention of symptoms has been recommended through several clinical trials. At present anti-inflammatory drugs (corticosteroids,cromolyn, nedocromil) followed by bronchodilators ( $\beta_{2}$ agonist, theophylline) and anti-cholinergics serve as the mainstay of treatment.[3]Herbal remedies are used for the treatment of asthma, since time immemorial. Several modern treatments have their origin from the folk medicine tradition. However no controlled clinical trials of herbal medicine have been reported.

Ferula asafetida is an indigenous plant belongs to family Apiceae, obtained from its rhizomes and roots. Asafetida has been used as a flavoring spice in Indian foods. One of the most important traditional use is for asthmaand cold cough.[4-6]In Indian folk medicine, it is also used for different diseases like epilepsy, stomach ache, flatulence and fungal infections. [7-10]In Ayurveda it is used for treatment of pneumonia, cough, bronchitis and tuberculosis. [11,12]The extract of the plant has been reported to have spasmolyitc effect on histamine and acetylcholine induced contraction in guinea pig ileum.[13] Also recently the hypotensive, chemomodulatory and antioxidant property of ferula asafetida oleo-gum resin have been proved.[13-15]

With the above background the present study has been undertaken to evaluate the bronchoprotective effect of aqueous extract of ferula asafetida on histamineinduced bronchospasm in guinea pigs. The secondary objective of this study was to elucidate its potential effect on compound 48/80 challenged mast cell degranulation in rat mesenteric cells.

\subsection{Plant and extraction:}

\section{Materials And Method}

Ferula asafetida gum resin was purchased from local market and was authenticated by National Institute of herbal science, PARC, Chennai. The dried gum was soaked in distilled water, boiled for 5 minutes 
and the decoction was allowed to stand for 30 minutes. After filtering, the concentration of stock solution was $200 \mathrm{mg} / \mathrm{ml}$. For anti- asthmatic effect, the aqueous extract was prepared freshly before use.

\subsection{Chemicals:}

Histamine di-hydrochloride and compound 48/80 were purchased from Sigma-Aldrich Chemical Co. USA. All other chemicals were purchased from Himedia Pvt. Ltd., India and were of analytical grade.

\subsection{Qualitative phytochemical screening:}

The extract was subjected for phytochemical tests to find out the presence of major phytochemicals such as carbohydrates, proteins, alkaloids, sterols, flavonoids, phenolic compounds, and fixed oils etc. as per standard methods. [16]

\subsection{Animals:}

Healthy guinea pigs $(n=30)$ of either sex, weighing between 300-450 grams were selected for this study. The animals were maintained in central animal house in standard conditions of temperature $\left(22 \pm 2^{\circ} \mathrm{C}\right)$, relative humidity $(55 \pm 5 \%)$ and light (12hrslight/dark cycle). The animals had free access to standard diet and water ad libitum; however, they were fasted overnight before the day of experiment. The protocol of the present study was approved by Institutional Animal Ethics Committee (IAEC) and the experiments were performed as per CPCSEA guidelines.

\section{4: Histamine induced bronchospasm in guinea pigs:}

For this study the method of Kallos and Pagel (1937), modified by Gujuralet at (1956) was followed. $[17,18]$ Guineapigs were exposed to $0.5 \% \mathrm{w} / \mathrm{v}$ of histamine di-hydrochloride aerosol blown into the chamber through the nebulizer under $300 \mathrm{~mm} \mathrm{Hg}$ pressure. The end point pre convulsive dyspnea (PCD) was determined from the time of aerosol exposure to the onset of dyspnea leading to the appearance of convulsion. Any animal without pretreatment of drugs, if does not develop the typical features of asphyxia for more than three minutes, the animal was considered as resistant and such animals were excluded from the experiment.

\section{5: Experimental design:}

Thirty guinea pigs of either sex, weighing between $300-450$ grams showing PCD of mean $80.0 \pm 2$ SD were randomlydivided into 5 groups of 6 in each. Their pre-drug treatment PCD time was noted as 0 day value.The vehicle and different drugs were administered orally once a day for 7 days. Gr-I served as control and received $5 \mathrm{ml}$ of distilled water, group II was given with terbutaline $0.02 \mathrm{mg} / \mathrm{kg}$. Aqueous extract of ferula asafetida was administered to Group III, IV, V animals with doses of 5,10 and $20 \mathrm{mg} / \mathrm{kg}$ body weight respectively. On day 7, two hour after the drug treatment the animals were re-exposed to histamine aerosol to record the time for onset of PCD. The percentage protection offered by drugs was calculated as follows. [19, 20] 'Percentage protection $(\%)=1-\mathrm{C} / \mathrm{T} \mathrm{X}$ 100'

Where, $\mathrm{C}=$ time for onset of PCT on day 0 , $\mathrm{T}=$ time for onset of PCD on day 7

One overnight fasted Wistar albino rat was sacrificed by cervical dislocation. The abdomen was incised to expose intestine with mesentery. The small pieces of mesentery were cut and put into petridishes containing Ringer Locke solution ( $\mathrm{NaCl} 154, \mathrm{KCl} 5.6, \mathrm{CaCl}_{2} 2.2, \mathrm{NaHCo}_{3} 6.0$ and dextrose 5.5 in $\mathrm{mM}$ )and different drug solutions. Six pieces of tissues were used for each concentration of the test solution. Mesenteries were then subjected to following treatments. Petri dish noI : vehicle control (ringer Locke solution only), Petri dish no II: negative control ( $0.8 \mu \mathrm{g} / \mathrm{ml}$ of compound C 40/80), Petridish no III: Positive control (sodium cromoglycate $1 \mathrm{mg} / \mathrm{ml}$ ), Petri dish no IV -VI: ferula asafetida solution $1,10,100 \mu \mathrm{g} / \mathrm{ml}$ respectively. After incubation for 30 minutes, the tissues from all groups except Gr I were exposed to compound C48/80 to induce mast cell degranulation and incubated for 30 minutes. Then the tissues were removed, trimmed and dipped in $4 \%$ formaldehyde solution containing $0.1 \%$ O-toludine blue for 20 minutes. The tissues were processed with to acetone and xylene. The stained mesentery pieces were examined under microscope at 100X magnification. 100 mast cells were counted for each tissue sample and the percentage of normal anddisrupted mast cells were calculated. A mast cell was defined to be disrupted if 4 or 5 granules were observed around the mast cell.[21]

\section{6: Statistical analysis:}

The data obtained were expressed as Mean \pm SEMand analyzed by one - way ANOVA followed by Tukey'smultiple comparison ' $t$ ' test using Graph pad Prism version 5.0. $\mathrm{p}$ value less than 0.05 was considered significant.

\section{Results}


Data depicted in this table revealed that with asafetida (5mg/kg body wt.) the mean PCD time $(93.67$ \pm 6.71 secs.) was not significantly altered from its pre-drug value $(82.17 \pm 4.3$ secs.). Whereas asafetida $10 \mathrm{mg} / \mathrm{kg}$ body wt. showed a significant prolongation ( $\mathrm{p}<0.001)$ in the mean PCD time $(130.17 \pm 7.51 \mathrm{sec})$ from its pre - drug value $(82.5 \pm 4.98 \mathrm{sec})$. A similar observation was found with asafetida $20 \mathrm{mg} / \mathrm{kg}$ body weight where the pre-drug treatment PCD time $(78.83 \pm 6.20 \mathrm{sec})$ was significantly increased $(\mathrm{p}<0.001)$ to $150.5 \pm$ 11.09 secs following treatment. Post ANOVA multiple ' $t$ ' test revealed that, the post drug PCD time with Asafetida 10 and $20 \mathrm{mg} / \mathrm{kg}$ were significantly prolonged in comparison to control group ( $\mathrm{p}<0.001)$ but not comparable to terbutaline.

Table-1:Comparison table showing the effect of asafetida (po for 7 days) onhistamine induced bronchospasm.

\begin{tabular}{|c|c|c|c|c|}
\hline \multirow[b]{2}{*}{$\begin{array}{l}\text { Group } \\
(\mathrm{n}=6)\end{array}$} & \multirow[b]{2}{*}{$\begin{array}{c}\text { Drug \& } \\
\text { dose }(\mathrm{mg} / \mathrm{kg})\end{array}$} & \multicolumn{2}{|c|}{ Mean PCD time \pm SEM ( seconds) } & \multirow[b]{2}{*}{$\begin{array}{c}\% \\
\text { protection }\end{array}$} \\
\hline & & Before treatment & After treatment & \\
\hline I & Distilled water- $5 \mathrm{ml}$ & $87.50 \pm 3.88$ & $90.00 \pm 4.08$ & 2.78 \\
\hline II & Terbutaline- 0.02 & $81.8 \pm 3.81$ & $189.67 \pm 10.37 * * *$ & 56.85 \\
\hline III & Asafoetida -5 & $82.17 \pm 4.30$ & $93.67 \pm 6.71$ & 12.28 \\
\hline IV & Asafoetida-10 & $82.50 \pm 4.98$ & $130.17 \pm 7.51 * * * a$ & 36.62 \\
\hline $\mathrm{V}$ & Asafoetida-20 & $78.83 \pm 6.20$ & $150.50 \pm 11.09 * * * a$ & 47.62 \\
\hline
\end{tabular}

Again the aqueous extract of asafetida gum with $5,10,20 \mathrm{mg} / \mathrm{kg}$ body wt. offered an excellent protection in guinea pigs against the histamine induced bronchospasm in a dose dependent manner $(12.28 \%, 36.62 \%, 47.62 \%$ respectively).

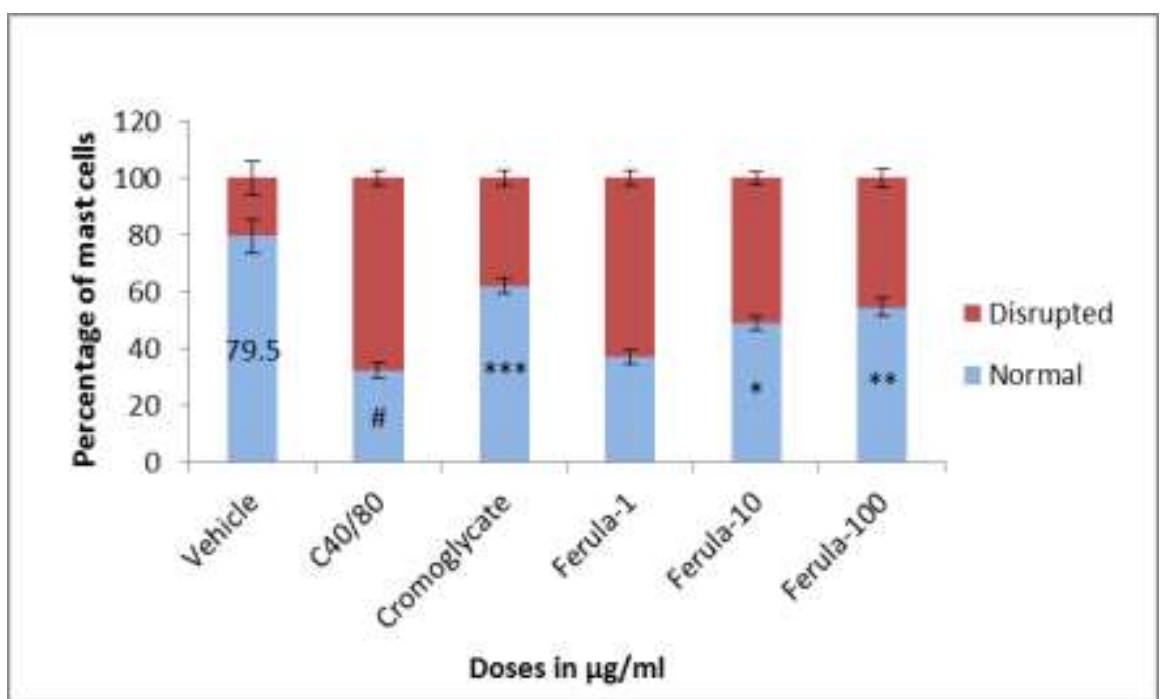

FIG-1:Effect of Ferula extract on Mast cell degranulation induced by compound 40/80 in rat mesentry. $\mathrm{n}=6$ in each dish. Data expressed as Mean \pm SE. Post ANOVA Tukey's multiple comparison test was applied. \#: $\mathrm{p}<0.001-\mathrm{C} 48 / 80$ vs DW, *: $\mathrm{p}<0.05,{ }^{* *}$ : $\mathrm{p}<0.01$ when compared with C $48 / 80$

Fig -1 revealed that Compound $48 / 80$ produced significant $(\mathrm{p}<0.001)$ reduction in percentage of intact mast cells (32.17 \pm 2.76$)$ in comparison to vehicle solution.(79.5 \pm 5.93$)$ Sodium cromoglycate increased the intact mast cell percentage against $\mathrm{C} 48 / 80$ challenge to a highly significant extent $(\mathrm{p}<0.001)$ in comparison only $\mathrm{C} 48 / 80$ challenged solution. (62.0 \pm 2.73 vs $32.17 \pm 2.76)$ In comparison to Petri dish II solution, Ferula with 10 and $100 \mu \mathrm{g} / \mathrm{ml}$ showed significant increase in intact mast cells to $48.83 \pm 2.24$ and $54.5 \pm 3.13$ respectively in C48/80 challenged tissues. $(\mathrm{p}<0.05,<0.01$ respectively)

\section{Discussion}

The traditional use of ferula asafetida for cough and respiratory problem was scientifically explained in this study. Results of the present study emanated that terbutaline, the reference standard drug and ferula asafetida with 10 and $20 \mathrm{mg} / / \mathrm{kg}$ significantly prolonged the mean PCD time against histamine induced bronchospasm. Again Ferula asafetida offered a highly significant protection in a dose dependent manner. The possible mechanism of bronchoprotective effect of ferula could be due to relaxation of bronchial smooth muscle against histamine induced bronchoconstriction. M Fatehiet al have reported that the relaxant compounds of 
ferula extract interfere with a variety of muscarinic, adrenergic and histamine receptor activities.[13] Also nonspecific inhibition of calcium ion could be a possible relaxant effect. They also evaluated the hypotensive effect of asafetida gum extract by its relaxant effect on vascular smooth muscle. [13]Several other studies have also evaluated the anti-inflammatory, anti-allergic, PAF antagonizing activities of ferula. [22]

It is well known that Compound 48/80 (a condensation product of $\mathrm{N}$ - methyl-p methoxyphenethylamine with formaldehyde) has potential to secrete allergy mediated factors as stimulators.Vigorously it can stimulate release of histamine from mast cells by cellular exocytosis. Hence Compound 48/80 induced mast cell degranulation model is used to test mast ell stabilizing effect. [23]Reduction in number of degranulated mast cell is a measure of mast cell stabilizing effect. Sodium cromoglycateinhibits the release of histamine and other mediators of inflammation. [24] The mast cell stabilizing activity of ferula could contribute to reduce mucous secretion in bronchial tree and reduce inflammation. Thus the bronchoprotective effect of ferula asafetida could be explained by multifactorial mechanism.

Phytochemical analysis showed presence of volatile oils, resins, ferulic acid, terpenes, flavonoids, steroids and sugar derivatives. These compounds are known to possess anti-bacterial, antioxidant, anti-cancer and spasmolytic activities. [25] Several flavonoids have been shown to possess smooth muscle relaxant and bronchodialator activity. [26] Flavonoids also can inhibit histamine release from mast cells.[27]As mast cell play a vital role in allergic asthma and rhinitis, mast cell stabilizing drugs are used for treatment and prophylaxis of asthma. [28] So the bronchoprotective activity of aqueous extract of ferula might be due to the presence of above constituents.

\section{Conclusion}

Results of the present study conclude that Ferula asafetida possesses bronchoprotective activity. Other experimental and clinical studies are needed to establish the scientific basis of the traditional use of Ferula in various respiratory illnesses.

\section{References}

[1]. McFadden ER JR: Evolving concepts in the pathogenic and management of asthma. Adv. Intern. Med 1994; $39: 357$.

[2]. ShelhamerJH,LevinSJ,Wu T, Jacoby DB: NIH conference: Airway inflammation. Ann Intern Med1995; 123:288

[3]. NHLBI guideline 2007; 123-124

[4]. GernotKatzer's Spice Pages, 18 oct,2003, www.ibiblio.org/herb

[5]. Felter HW, The Eclectic MateriaMedica, Pharmacology and Therapeutics.1992.

[6]. Srinivasan K. Spices as influencers of body metabolism: an overview of three decades of research. Food Res Int. 2005; 38(1):7786. doi:10.1016/j.foodres.2004.09.001.17.

[7]. Takeoka G. Volatile Constituents of Asafoetida, Aroma Active Compounds in Foods. America Chem Soc. 2001;794:33-44. doi: 10.1021/bk-2001-0794.ch004.

[8]. Lee CL, Chiang LC, Cheng LH, Liaw CC, Abd El-Razek MH, Chang FR, et al. Influenza A (H(1)N(1)) Antiviral and Cytotoxic Agents from Ferula assa-foetida.J Nat Prod. 2009;72(9):1568-72. doi: 10.1021/np900158f. [PubMed: 19691312]

[9]. Evans WC. Trease and Evans Pharmacognosy. London: Saunders; 2002. p.286.

[10]. Angelini P, Pagiotti R, Venanzoni R, Granetti B. Antifungal and allelopathic effects of Asafoetida against Trichodermaharzianum and Pleurotus spp. Allelopathy J. 2009;(23):357-68.

[11]. Kapoor LD. Handbook of Ayurvedic Medicinal Plants. 1 ed. Washington, D.C.: CRC Press; 2001.18

[12]. Appendino G, Maxia L, Bascope M, Houghton PJ, SanchezDuffhues G, Munoz E, et al. A meroterpenoid NF-kappaB inhibitor and drimanesesquiterpenoidsfrom Asafetida. J Nat Prod. 2006;69(7):1101-4. doi: 10.1021/np0600954. [PubMed: 16872156]

[13]. Mohammad Fatehi, FreshtehFarifteh and Zahra Fatehi-Hassanabad. Antispasmodic and hypotensive effects of Ferula asafetida gum extract. Journal of Ethnopharmacology, 2004; 91, (2-3): 321-324

[14]. Mallikarjuna GU, Dhanalakshmi S, Raisuddin S, Rao AR. Chemomodulatory influence of Ferula asafetida on mammary epithelial differentiation, hepatic drug metabolising enzymes, antioxidant profiles and $\mathrm{N}$-methyl-N-nitrosourea-induced mammary carcinogenesis in rats. Breast Cancer Res Treat . 2003;81:1-10.

[15]. Saleem M, Alam A, Sultana S. Asafoetida inhibits early events of carcinogenesis: a chemopreventive study. Life Sci . 2001;68:1913-1921.

[16]. Kokate C K.Practicalpharmacognosy, 2nd ed, New delhi: Vallabhprakasham; 1988. P. 142-159

[17]. Kallos, P. and Kallos, L. Acta Med Scand. 1937; 91: 292.

[18]. Gujral et al. Post graduate Med. 1956; 11. 166: 1

[19]. Sheth UK, Dadkar NK. Kamat NG. Selected topics in experimental pharmacology.Mumbai, India: Kothari Book Depot: 1972.

[20]. Armitage AK, Boswood J, Large BJ. Thioxanthines with potent bronchodilator and coronary dilator properties. Br Pharm Chemother $1961 ; 16: 59-76$.

[21]. Norton S. Quantitative determination of mast cell degranulation by Compound 48/80. Br J Pharmacol. 1954; 9: 494-497

[22]. Winston. D,- MateriaMedica Notes, HTSBM, Washington, NJ-1992-2002

[23]. Barnes PJ, Chung KF, Page CP. Inflammatory mediators of asthma: An update. Pharmacol Rev 1998; 50:515-96.

[24]. H T Holgate.Reflections on the mechanism(s) of action of sodium cromoglycate (Intal) and the role of mast cells in asthma. Respiratory medicine. May 1989; 83 Suppl: 25-31

[25]. Rekha S Singhal, Puspa R Kulkarni.Handbook of Indices of food qualityand authenticity. 1997; 395

[26]. Hazekamp A, Verpoorte R, Panthong A. Isolation of bronchodilator flavonoid from the Thia medicinal plant Clerodendrumpetasites. J Ethnopharmaco2001;78:45-9.

[27]. Bellanti JA. Mechanism of tissue injury produced by immunologic reactions. Immunology. Asian ed. Tokyo: W.B. Saunders Co; 1971. p. 184.

[28]. Peachell P. Targeting the mast cell in asthma. CurrOpinPharmacol 2005; 5:251-6. 